\title{
Maxillary Sinus Cancer pT1 TNM Finding v8
}

National Cancer Institute

\section{Source}

National Cancer Institute. Maxillary Sinus Cancer pT1 TNM Finding v8. NCI Thesaurus.

Code C133035.

Maxillary sinus cancer with tumor limited to the maxillary sinus mucosa with no erosion or destruction of bone. (from AJCC 8th Ed.) 